\title{
A preliminary effort to reduce carcinogenic polycyclic aromatic hydrocarbons from diesel exhaust by using different blends of diesel and synthesized biodiesel
}

\author{
Kumar V. ${ }^{1,}{ }^{*}$, Vikas P. ${ }^{2}$, Saruchi ${ }^{3}$, Sharma R. ${ }^{2}$, Masih A. and Kothiyal N.C. ${ }^{5}$ \\ ${ }^{1} \mathrm{ECL}$, Department of Applied Sciences, CT Group of Institutions, Jalandhar, Punjab, India \\ ${ }^{2}$ Department of Bio Technology, DAV University, Jalandhar, Punjab \\ ${ }^{3}$ NIMS, University of Rajasthan, India \\ ${ }^{4}$ ERL, Department of Chemistry, St. Andrew's College, Gorakhpur, India \\ ${ }^{5}$ Department of Chemistry, Dr. BRA, NIT Jalandhar, Punjab, 144011 \\ Received: 14/12/2017, Accepted: 14/04/2018, Available online: 06/08/2018 \\ *to whom all correspondence should be addressed: e-mail: vaneet2106@gmail.com
}

\begin{abstract}
In the present investigation an attempt for the reduction of six hazardous air Pollutants (HAPs) from diesel exhaust by different blends of diesel and biodiesel has been made. The synthesis of biodiesel has been done from Jetrofa, Linseed Castor and Karanja oils which are commonly used in the Indian market. Blending of diesel with biodiesel was done in different ratios (20 to $40 \%$ ) for the estimation of carcinogenic HAPs from the exhaust of a Honda engine (EBK 2010AC Model). The order of HAPs emission from engine exhaust by using diverse blends were

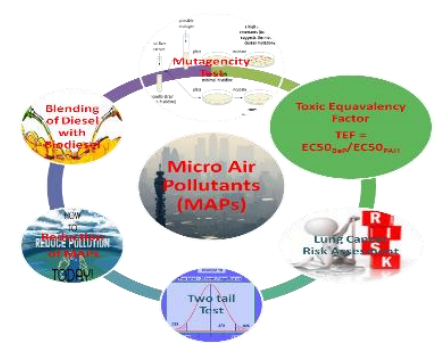

Diesel>Jatropha-diesel>Linseed-diesel>Castor-diesel> Karanja-diesel. The maximum reduction of HAPs was established in the following ratio $40 \%$ (Biodiesel):60\% (Diesel). B(a)P and Chrysene were the two individual aromatic hydrocarbons (AHCs) found in higher concentration in almost all blending fuels, ranging between $50 \mathrm{ng} / \mu \mathrm{l}$ to $101.1 \mathrm{ng} / \mu \mathrm{l}$. The emission of almost all AHCs reduces by Blending of Diesel with Biodiesel. This was the first comprehensive information which showed the reduction of carcinogenic pollutants from diesel exhaust.
\end{abstract}

Keywords: HAPs, AHCs, Diesel, Biodiesel, Carcinogenicity.

\section{Introduction}

Hazardous air pollutants (HAPs) established a broad family of compounds that are sometimes designated as mono and polycyclic organic compounds. This term refers to the fact that HAPs are distributed among gas and particle phases (Baek et al., 1991; Benner et al., 1989). The range of their vapor pressures is revealed to the fact that, at equilibrium and ambient temperature, mono aromatic hydrocarbons like benzene, toluene, xylene as well as two-ring hydrocarbons like naphthalene exists almost completely in the gas phase, whereas five ring and higher polycyclic aromatic hydrocarbons (PAHs) are mainly adsorbed on particulate matters. The intermediate of three- and fourring PAHs are distributed between the two phases. However, the gaseous concentrations of these intermediate PAHs can be considerably reduced by their adsorption and absorption on various types of surfaces (Caricchia et al., 1999; Kauppinen, 2001). Because of this phenomenon, the amount and type of particulate matter play a significant role, together with temperature, in the vapor-particle partitioning of semi volatile organic compounds.

Motor vehicles are one of the utmost common modes of transportation in numerous countries around the world (Satyarthi et al., 2009; Masih and Taneja, 2006). Some south Asian countries also falls into the same category where we have over one million buses which account for $17 \%$ of all the motor vehicles. The health risk associated with high number of motor vehicles in these countries is both significant and alarming. HAPs, including polycyclic as well as mono aromatic hydrocarbons (AHCs), were designated as the target compounds in learning for their carcinogenicity. An increased incidence of lung tumours, some of which were diagnosed as malignant, was detected in some studies with rats following exposure for two or more years to high levels of diesel exhaust emission. Studies with laboratory animals exposed to diesel exhaust and known carcinogens advice that exposure to diesel exhaust augments the effect of the known carcinogens (MCClellan, 1987). Thus, study of diesel-exhaust-induced carcinogenicity must be involved in addition to lung DNA adduct formation (Bond, 1990).

Literature survey indicates (Kumar et al., 2015) that inadequate research work has been done on air contamination and distribution behavior of AHCs in fast rising cities of India, where vehicles (cars, trucks, buses and 
two, three wheeler) as old as one to twenty years ply on the same roads. Lack of maintenance, poor planning, socio economic condition and slow pace of infrastructure development in developing country has multiplied the pollution problem further. Smaller vehicles (two, three and four wheelers) run principally on petrol and diesel fuels are major supplier of AHCs in the city atmosphere (Kumar et al., 2014). The increasing ultimatum of fossil fuels over the past decades due to urbanization, industrial development, increase in population and vehicular traffic has caused an escalation in the emission of AHCs to the atmosphere (Kumar and Kothiyal, 2012). To our acquaintance, there is no literature available on reduction of the particulate and AHCs emission from engine exhaust in India as well as abroad. The health risk linked with this high number of motor vehicles in countries is noteworthy and alarming.

This study targets to synthesize biodiesel from various oils available in local market. Blending of diesel with biodiesel was also done in diverse ratios for the estimation and reduction of carcinogenic AHCs (Kumar and Kothiyal, 2014). Biodiesel samples were synthesized in our lab from different raw materials and analyzed for AHCs concentration in exhaust of a Honda engine (EBK 2013AC Model) on standing mode.

\section{Materials and Methods}

\subsection{Synthesis of Biodiesel}

Biodiesel samples were synthesized indigenously in our laboratory using Jetrofa, Linseed, Castor and Karanja oil as raw materials procured from the local market.

\subsubsection{Catalyst Preparation}

A series of lithium ion impregnated $\mathrm{CaO}(\mathrm{Li} / \mathrm{CaO})$ catalyst was prepared by following the wet chemical method reported earlier (Abebe et al., 2011). In a typical preparation, $10 \mathrm{~g}$ of calcium oxide was suspended in $40 \mathrm{~mL}$ of deionized water, and to this $10 \mathrm{~mL}$ aqueous solution of $\mathrm{Li}_{2} \mathrm{CO}_{3}$ of desired concentration was added to obtain 0.5-5 wt\% $\mathrm{Li}$ in $\mathrm{CaO}$. The resulted slurry was stirred for 2 hours at room temperature $\left(30^{\circ} \mathrm{C}\right)$ and finally dehydrated at $120^{\circ} \mathrm{C}$ in oven for 24 hours. The prepared catalysts were designated as $x$-Li/CaO, where $x$ represents the wt\% of lithium in $\mathrm{CaO}$.

\subsubsection{Trans-esterification of waste cottonseed oil}

All transesterification reactions for biodiesel synthesis were carried out in $250 \mathrm{ml}$, three necked round bottom flask equipped with water cooled reflux condenser, thermometer, oil bath and a magnetic stirrer. In a typical run, the flask was charged with $10 \mathrm{ml}$ vegetable oil, desired molar concentrations of ethanol and desired amount of catalyst. To monitor the progress of the reaction, the aliquots were collected from the reaction mixture after every 15 min with the help of glass capillary and exposed to the NMR and GC-MS studies. After the accomplishment of the reaction, the solid catalyst was removed from the reaction mixture by filtration. The liquid phase was kept in separating funnel for 24 hours to separate the lower glycerol layer from the upper FAEEs layer. The extra ethanol from the later was recovered with the help of rotary evaporator. FAEEs, thus obtained, were further characterized and quantified by ${ }^{1} \mathrm{H}$ NMR and GC-MS techniques. Waste cotton seed oil derived FAEEs ${ }^{1} \mathrm{H}$ NMR $\left(\mathrm{CDCl}_{3}, \delta \mathrm{ppm}\right): 5.3(\mathrm{~m},-\mathrm{CH}=\mathrm{CH}-), 4.2\left(\mathrm{q},-\mathrm{OCH}_{2} \mathrm{CH}_{3}\right), 2.7$ $\left(\mathrm{m},-\mathrm{CH}=\mathrm{CH}-\mathrm{CH}_{2}-\mathrm{CH}=\mathrm{CH}-\right), 2.3\left(\mathrm{~m},-\mathrm{CH}_{2}-\mathrm{CO}-\right), 2.0(\mathrm{~m},-$ $\left.\mathrm{CH}_{2}-\mathrm{CH}=\mathrm{CH}-\right), 1.6-1.25\left(\mathrm{~m},-\left(\mathrm{CH}_{2}\right)_{\mathrm{n}}-\right), 0.95(\mathrm{~m},-\mathrm{CH}=\mathrm{CH}-$ $\left.\mathrm{CH}_{3}\right), 0.87\left(\mathrm{~m},-\mathrm{CH}_{2}-\mathrm{CH}_{3}\right)$.

\subsection{Chemicals}

HPLC grade reagents, solvents and standards used in the study were procured from Merck specialty Chemicals, Pvt. Ltd. Mumbai, India. AHCs standards used in GC studies were procured from $\mathrm{Dr}$ Ehrenstorfer $\mathrm{GmbH}$ Chemicals, Merck, Germany Pvt. Ltd.

\subsection{Glasswares}

All glassware's of Borosil make glass (A grade) were used in the study. Glassware's were dipped in dilute Nitric acid and washed with plain and double distilled water every time before use

\subsection{Sampling site description}

Punjab is one of the prospering and fast budding states of India. Jalandhar, one of the major intensifying cities sited at the centre of Punjab between Beas and Sutlej rivers. The city, which has key road and rail connections, is a market for agricultural, textile, leather goods, wood products, hand tools and sports material. Jalandhar is located at $710^{\circ}$ $31^{\prime}$ East and $300^{\circ} 33^{\prime}$ North at a distance of 146 kilometers from state capital Chandigarh on Delhi-Amritsar National Highway (grand trunk road). According to 2011 Census (provisional), the area of Jalandhar district is 3,401 sq.km and total population of the district was 2,753,508 persons (Kumar and Kothiyal, 2011b). The city has shown spectacular growth in terms of population, infrastructure and traffic thickness during last few years. The weather of this district is on the whole dry except during the brief south-west monsoon season (July to September). The average annual rainfall in the district is $703.0 \mathrm{~mm}$ (Kumar and Kothiyal, 2014a). The monitoring station was situated at National Institute of Technology Jalandhar (NIT) gate on Amritsar-New Delhi National Highway in the outskirt of the city with large open area on both side of the road. The traffic pace was much fast, but density was low at this site (with majority of heavy vehicle i.e., truck car and buses). The traffic volume of the station was high (around 50,000 vehicles daily) with majority of two, three and four wheelers. Figure 1 shows the map of Jalandhar representing sampling site. 


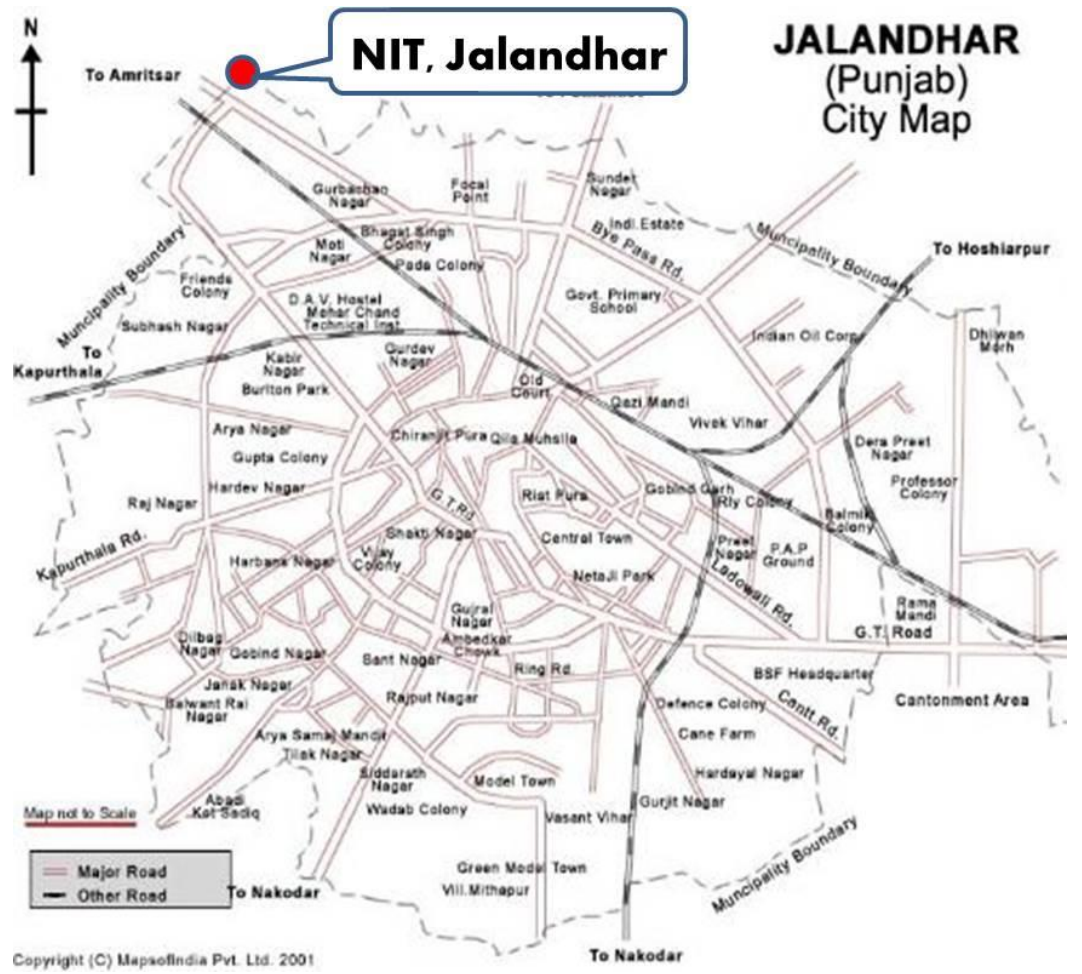

Figure 1. Map of Jalandhar showing sampling site

\subsection{Sampling Method}

The samples were collected as per Method TO-15A (USEPA, 2009). Sampling was done with high volume sampler Model APM-411 (Envirotech Instruments Pvt. Ltd. New Delhi). Exhaust pipe from Honda engine exhaust was left at the canopy of High volume sampler. High volume sampler collects the particulate matters in the size range 100-0.01 $\mu \mathrm{m}$. The glass microfibre filter paper GF/A $(20.3 \times 25.4 \mathrm{~cm})$ were used for sampling. Before fitting the filter paper in the instrument, it was dehydrated in hot oven at $40{ }^{\circ} \mathrm{C}$ for 1 hour. The exhaust samples were drawn in a laminar flow at the rate $1-1.2 \mathrm{~m}^{3} / \mathrm{min}$. The airborne particles comprising AHCs adsorbed on it were collected for 9- 10 hours (during peak traffic density hours) on filter paper. Vapor phase (low molecular weight) AHCs were trapped by means of glass microfibre filter paper followed by Polyurethane Foam (PUF) fixed just below the filter paper in a cartridge. Filter paper and PUF was removed from the machine and preserved in a vacuum desiccator stored in dark till analysis. Sampling period was 9.5 hours. A total of 12 samples were collected for analysis as follow: Jatropha:Diesel (20:80), Jatropha:Diesel (30:70), Jatropha:Diesel (40:60), Linseed:Diesel (20:80), Linseed:Diesel (30:70), Linseed:Diesel (40:60), Castor:Diesel (20:80), Casor:Diesel (30:70), Castor:Diesel (40:60), Karanza:Diesel (20:80), Karanza:Diesel (30:70), Karanza:Diesel (40:60). Weather condition during the sampling period are given in the table 6. Sample were collected and analyzed in between the month of March and April 2017.

Table 6. Meteorological parameters and SPM concentration of sampling sites for the period May 2016 to April 2017

\begin{tabular}{cccccc}
\hline Sr. No. & Month & Average Temperature $\left.{ }^{\mathbf{}}{ }^{\mathbf{C}} \mathbf{C}\right)$ & $\begin{array}{c}\text { Relative wind } \\
\text { speed }^{\mathbf{( K m} / \mathbf{h})}\end{array}$ & $\begin{array}{c}\text { Relative Humidity } \\
(\mathbf{\%})\end{array}$ & $\begin{array}{c}\text { Average SPM }^{\mathbf{a}} \\
\left(\boldsymbol{\mu g} / \mathbf{m}^{\mathbf{3}}\right)\end{array}$ \\
\hline 1 & May & 30.11 & 6.11 & 28.11 & 399 \\
\hline 2 & June & 36.51 & 13.11 & 32.21 & 457 \\
\hline 3 & July & 37.71 & 9.01 & 51.10 & 459 \\
\hline 4 & August & 35.52 & 12.11 & 53.01 & 497 \\
\hline 5 & September & 32.11 & 8.11 & 67.12 & 199 \\
\hline 6 & October & 29.91 & 8.02 & 66.22 & 195 \\
\hline 7 & November & 28.21 & 6.01 & 53.10 & 355 \\
\hline 8 & December & 22.01 & 5.04 & 57.08 & 422 \\
\hline 9 & January & 19.21 & 5.24 & 56.84 & 589 \\
\hline 10 & February & 15.11 & 5.20 & 65.51 & 319 \\
\hline 11 & March & 18.50 & 6.82 & 59.05 & 335 \\
\hline 12 & April & 21.61 & 11.17 & 47.54 & 318 \\
\hline
\end{tabular}

Source: Punjab Meteorological Department (PMD), Jalandhar, India. 


\subsection{Extraction and analysis}

AHCs both adsorbed on particulate and semi volatile phase were extracted from filter paper and PUF using soxhlet extractor in toluene for 20 to 24 hours at the rate of 3 cycles per hour. Toluene was used instead of other solvents (like benzene/methanol, dichloro methane (DCM), etc.) due to its high recovery, especially for higher boiling AHCs (Kumar et al., 2014). Combined extract of filter paper and PUF was concentrated to $1 \mathrm{ml}$ volume in rotary flash evaporator at $60^{\circ} \mathrm{C}$ under gentle vacuum. Temperature of the water bath was kept below $40^{\circ} \mathrm{C}$ to rule out any possibility of breakdown. The extract was transferred to a $10 \mathrm{ml}$ volumetric flask and then the volume was adjusted to 10 $\mathrm{ml}$ with hexane. Impurities were removed by liquid-solid chromatography using silica gel (70-230 mesh) activated at $250{ }^{\circ} \mathrm{C}$ for 24 hours. The silica gel slurry in hexane was packed as a glass column $(0.6 \mathrm{~cm}$ internal diameter). The concentrated extract was transferred to the top of the column and eluted with $10 \mathrm{ml}$ of hexane followed by $20 \mathrm{ml}$ of $1: 1$ solution of toluene and hexane. The eluate thus obtained was evaporated nearly to dryness using the rotavapor below $40^{\circ} \mathrm{C}$. The reduced volume of sample was dissolved in HPLC grade toluene before injecting in gas chromatograph (USEPA, 2009). The sample was kept preserved in an amber colour sample tubes in refrigerator at below $4{ }^{\circ} \mathrm{C}$ till analysis. The exhaust samples were examined on Nucon make microprocessor-based Gas Chromatograph, (Model No 5765) on RH - 5 capillary column (30 meter length, 0.53 ID $\times 3.0 \mu \mathrm{m}$ ) using Flame Ionization Detector. The injection and detector temperature were kept $280{ }^{\circ} \mathrm{C}$ and $300{ }^{\circ} \mathrm{C}$, respectively. Injection volume on $\mathrm{GC}$ was $1 \mu \mathrm{l}$. The temperature was programmed for $90^{\circ} \mathrm{C}$ for $0.5 \mathrm{~min}$, followed by $30^{\circ} \mathrm{C} / \mathrm{min}$ to $290 \quad{ }^{\circ} \mathrm{C}$; hold for 5 minutes and $30^{\circ} \mathrm{C}$ to $320^{\circ} \mathrm{C}$ hold for 4 minutes. The carrier gas used was $\mathrm{N}_{2}(2 \mathrm{ml} / \mathrm{min})$. Rotavapor and soxhlet extraction apparatus were used to extract and concentrate the MAPs. The process described above has been checked for recovery efficiencies using spiked MAPs standard. Recovery range between $30 \%$ and $70 \%$ with the lower value corresponds to the lower molecular weight MAPs compound. Presented data is corrected accordingly with the mean of triplicate analysis. Replicated analysis give an error between $\pm 10 \%$ and $\pm 20 \%$. More than one internal standard that is similar in analytical behavior to the compounds of interest were selected. The measurement of the internal standard is not exaggerated by method or matrix interference. The following deuterated AHCs compounds were used to prespike the sample extracts: Napthalene $d_{8}$; Acenapthene $d_{10}$; Fluorene $d_{10}$, Phenanthrene $d_{10}$; Benzo(a)anthracene $d_{12}$; Chrysene $d_{12}$ and Perylene $d_{12}$. The base peak ion was used as the principal ion for quantification of the standard compounds. Four concentration levels calibration standard solutions of AHCs was prepared at a minimum of by adding appropriate volumes of one or more stock standard solutions to a conical flask. The stock standard solutions were prepared from certified solutions of $2000 \mu \mathrm{g} / \mathrm{mL}$ of each analyte of interest (Merk, Germany). The solutions of stock standard were prepared at concentrations of $100 \mu \mathrm{g} / \mathrm{ml}$ in toluene. A calibration table is created from instrument responses for target compound challenge concentrations of 25,50, 100 and $250 \mathrm{ng} / \mathrm{nL}$. To each calibration standard solution, $100 \mathrm{ng} / \mu \mathrm{L}$ of deuterated internal standard was inserted. Calibration standard solutions were at a concentration near but above the maximum detection limit and the other concentrations should correspond to the expected range of concentrations found in real samples or define the working range of the Gas Chromatograph. RF value on the working range was kept constant ( $<10 \% \mathrm{RSD}$ ), the $\mathrm{RF}$ assumed to be invariant and the average RF was used for calculations. Alternatively, the result was used to plot a calibration curve of response ratios, As/Ais vs. RF. The working calibration curve or RF was verified on each working day by the measurement of one or more calibration standard solutions. If the response for any analyte varies from the predicted response by more than $\pm 10 \%$, the test was repeated using a fresh calibration standard solution (Kumar et al., 2014).

\section{Results and Discussion}

The characterized physical properties of biodiesel samples synthesized in the present study are given in Table 1 and Table 2. All the values were approximately similar to the values accepted in EN and ASTM standards as reported in literature (Ayhan, 2009; Kumar et al., 2014). The physical parameter of biodiesel indicated that vegetable oils (Castor, Linseed, Karanja and Jatropha) were in between $96 \%$ to $99 \%$ when converted in to the biodiesel. The mean concentration of six ACHs is depicted in Figure 2.

Table 1. Physical properties of the biodiesel samples

\begin{tabular}{|c|c|c|c|c|c|c|}
\hline \multirow{2}{*}{ Physical Parameter } & \multicolumn{4}{|c|}{ Types of Biodiesel } & \multirow[b]{2}{*}{ Standard Limits } & \multirow[b]{2}{*}{ Standard Methods } \\
\hline & Jatropha & Linseed & Castor & Karanja & & \\
\hline Flash point $\left({ }^{\circ} \mathrm{C}\right)$ & 175.0 & 442.0 & 190.0 & 165 & $>101$ & EN 3679 \\
\hline Pour point $\left({ }^{\circ} \mathrm{C}\right)$ & 13.00 & 10.00 & 23.0 & 25 & $>10$ & ASTM D2500 \\
\hline Density $(\mathrm{g} / \mathrm{ml})$ & 0.86 & 0.85 & 0.92 & 0.89 & $0.86-0.90$ & EN 3675 \\
\hline Viscosity (Cst) & 5.20 & 2.90 & 3.20 & 2.1 & $1.9-5.0$ & ASTM D445 \\
\hline Acid value (wt\%) & 0.33 & 0.22 & 4.00 & 2.01 & $<0.5$ & EN 14104 \\
\hline lodine value (cg lodine/g oil) & 91.00 & 110.0 & 127.0 & 118 & $<120$ & EN 14111 \\
\hline Ester content (\%) & 99.00 & 100.0 & 96.0 & 95 & $>96.5 \%$ & $1 \mathrm{H}$ NMR \\
\hline
\end{tabular}


Table 2. Esters characterization using GC-MS

\begin{tabular}{ccc}
\hline Sr. No. & FAEEs & wt \% \\
\hline 1. & Palmitate & 34.13 \\
\hline 2. & Linoleate & 40.20 \\
\hline 3. & Stearate & 3.99 \\
\hline 4. & Oleate & 21.68 \\
\hline
\end{tabular}

The catalyst, 3-Li/CaO, was found to yield the $98 \pm 2 \%$ conversion

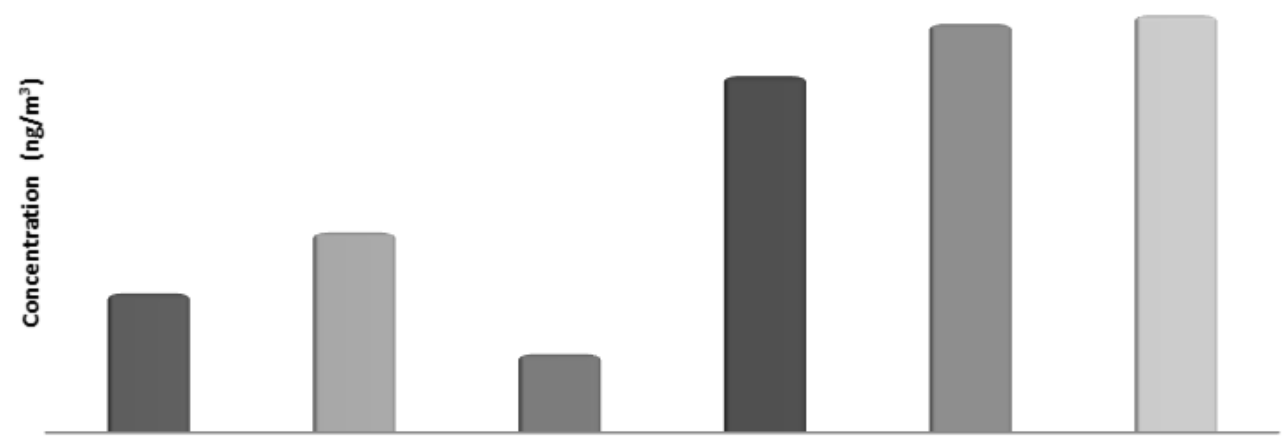

AHCs

Figure 2. Mean Concentration of AHCs

\section{$3.1{ }^{1} \mathrm{H} N M R$ of biodiesel samples and their raw material}

Biodiesel produced was further characterized and analyzed by ${ }^{1} \mathrm{H}$ NMR technique. The ${ }^{1} \mathrm{H}$ NMR spectra of vegetable oils (Figure 3) show a multiplet at 4.2-4.4 ppm due to the presence of glyceridic protons. The peaks in the range of 1.0-3.0 ppm (in the proton NMR spectra of biodiesel and vegetable oils) are due to the protons of the aliphatic hydrocarbon chain whereas the unsaturated protons in biodiesel as well as in vegetable oil appear at $5.4 \mathrm{ppm}$. In proton NMR spectra spectrum of biodiesel sample, disappearance of glyceridic protons (4.2-4.4 ppm) and appearance of a new peak at $3.6 \mathrm{ppm}$ due to $-\mathrm{OCH}_{3}$ protons support the formation of biodiesel after the transesterification reaction of vegetable oils. The Proton NMR spectra have also been used to quantify biodiesel by following the literature reported procedure (Kumar et al., 2014).

$\%$ Yield $=\left\{2 I_{(\text {methoxy })} / 3 I_{\text {(methylene) }}\right\} \times 100$ (1)

where $I_{\text {(methoxy) }}$ and $I_{\text {(methylene) }}$ are the areas of the methoxy and methylene protons, respectively, in ${ }^{1} \mathrm{H} N M R$ spectra of biodiesel.

$$
\begin{gathered}
\text { \%Yield }(\text { Castor bio diesel })=(2 \times 3.51 / 3 \times 245) \times 100=95.59=96 \% \\
\% \text { Yield }(\text { Linseed bio diesel })=(2 \times 3 / 3 \times 2.03) \times 100=98.52=99 \% \\
\% \text { Yield }(\text { Jatropha bio diesel })=(2 \times 1.17 / 3 \times .07) 100=100 \% \\
\% \text { Yield }(\text { Karanja bio diesel })=(2 \times 0.17 / 3 \times 1.07) 100=99.1 \%
\end{gathered}
$$

The biodiesel prepared from Linseed, Castor, Jatropha and Karanja oils shows complete conversion in Thin Layer Chromatography (TLC). In proton NMR analysis, the yield of prepared biodiesel samples comes out to be more than 96.5\%. Thus, the prepared biodiesel samples found to satisfy the specification as mentioned in EN and ASTM standards. According to the EN and ASTM standard when $\%$ yield of the biodiesel samples comes out more than 96 $\%$, it means that vegetable oil is complete converted in to the biodiesel oil. So our NMR spectra results indicate that our vegetable oil was complete converted in to the biodiesel samples. Blends of biodiesel and conventional hydrocarbon-based diesel are produced by mixing biodiesel and petroleum diesel in suitable proportions under appropriate conditions. Figure 4 depicts the mean concentration of AHCs generated by Jatropha, Linseed Karanza and Castor biodiesel/diesel blends.
The results of AHCs concentration produced by diesel and different biodiesel ratios $(20: 80,30: 70$ and $40: 60)$ have been represented in Table 3 . The results clearly demonstrate that diesel fuel generated highest concentration of AHCs (36.36 $\mu \mathrm{g} / \mathrm{L})$. Table 3 also specifies that out of the four BD blends, Jatropha levels were dominant among all the ratios (20:80, 30:70 and 40:60) of biodiesel having 23.64, 19.26 and $17.63 \mu \mathrm{g} / \mathrm{L}$ respectively, followed by Linseed (21.49, 18.13 and $15.43 \mu \mathrm{g} / \mathrm{L})$, Castor (19.05, 16.11 and $14.01 \mu \mathrm{g} / \mathrm{L})$ and Karanza (13.28, 11.21 and $9.21 \mu \mathrm{g} / \mathrm{L}$ ) BD blends. It is evident from Figure 5 that when concentrations of the blends increase from 20:80 to 40:60 then concentration of all AHCs decrease as compared to the pure diesel. 

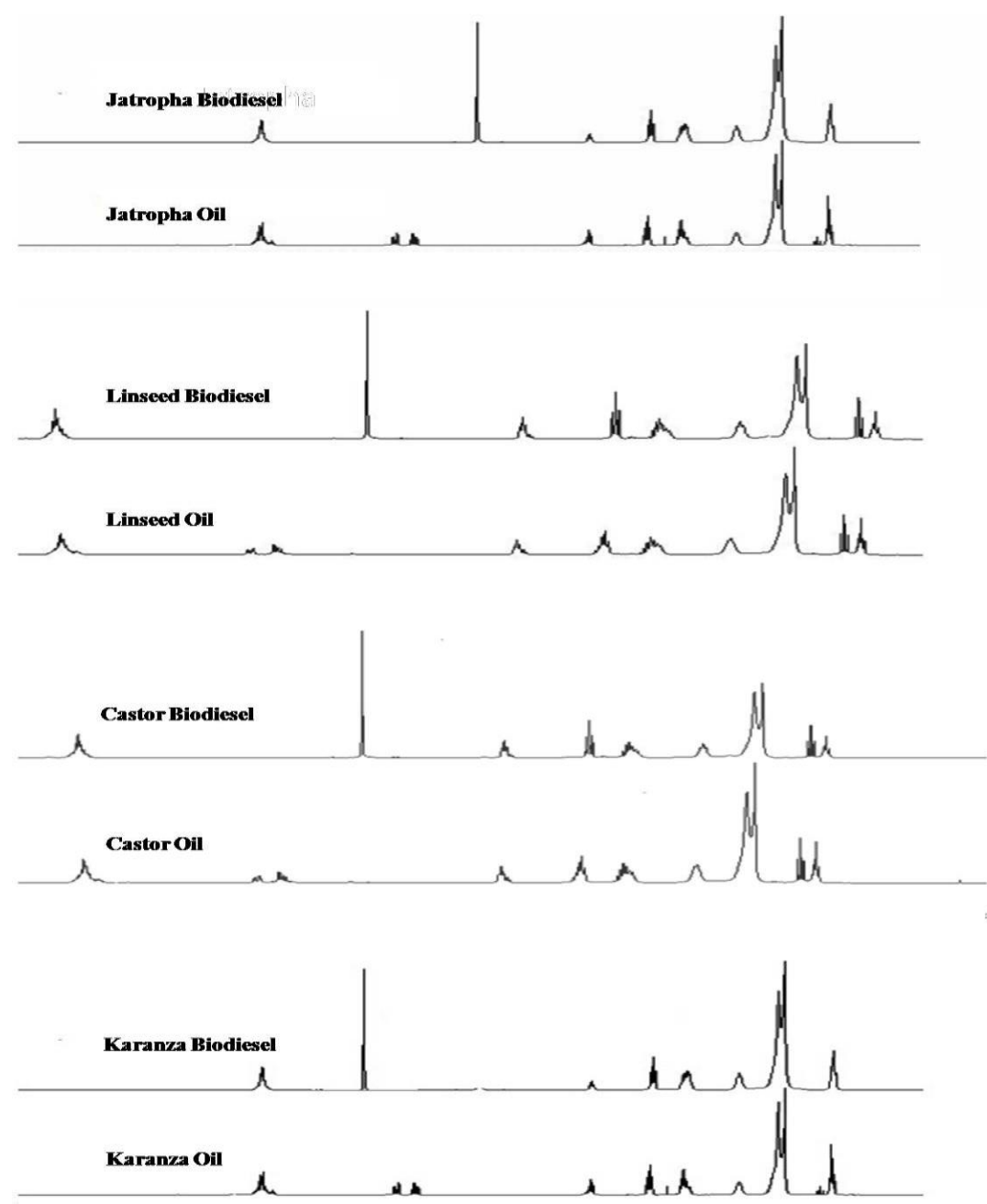

Figure 3. $\mathrm{H}^{1} \mathrm{NMR}$ spectra of peaks different biodiesel and oils
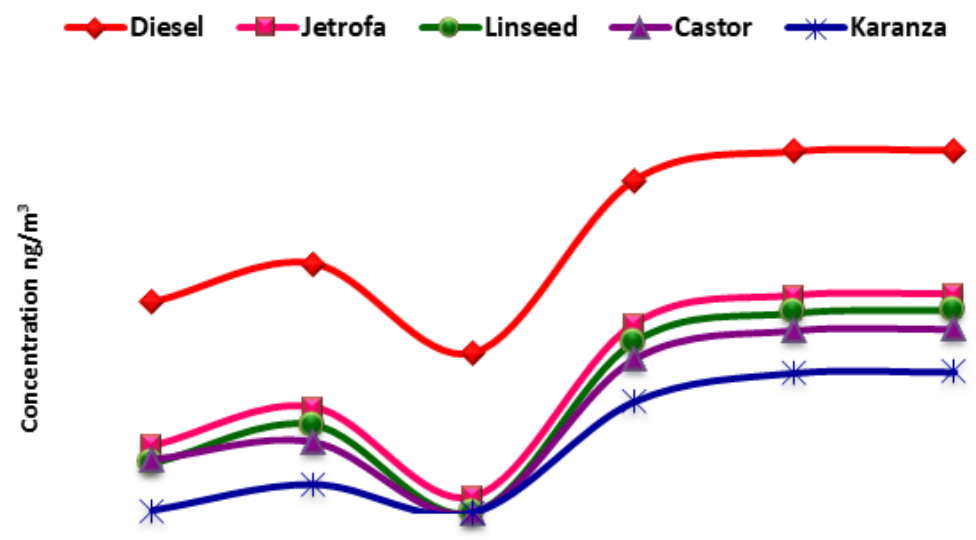

Figure 4. Mean concentration of AHCs generated by Jatropha, Linseed Karanza and Castor biodiesel/diesel blends 

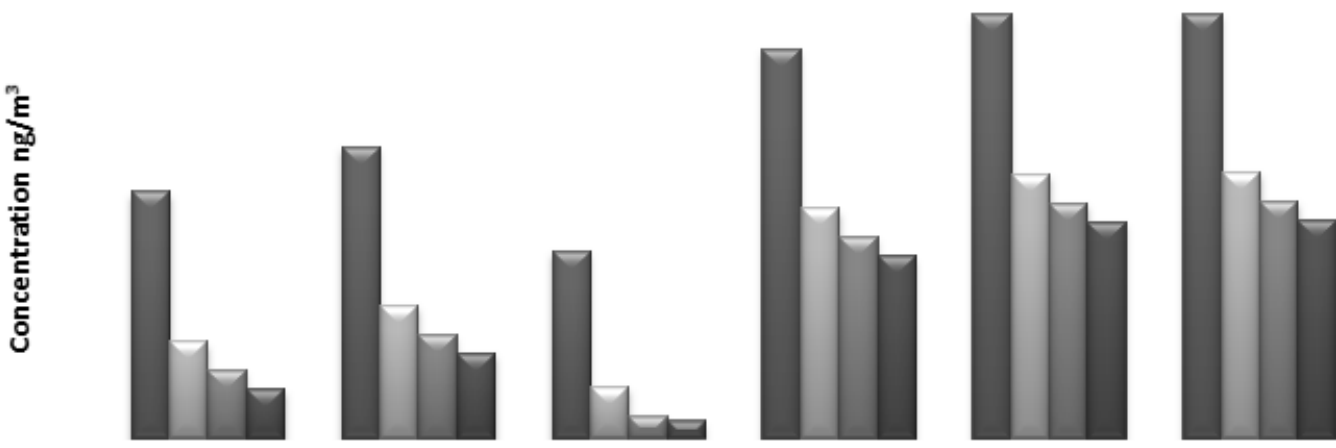

Figure 5. Decreasing trend of $\mathrm{AHC}$ levels from pure diesel to 40:60 ratio

Figure 6 illustrates that the order of emission of AHCs from the exhaust of engine were in the order of Diesel (39\%) > Jatropha-diesel $(19 \%)>$ Linseed-diesel $(17 \%)>$ Castordiesel $(15 \%)>$ Karamza-diesel $(10 \%)$. As per our knowledge this was the first comprehensive information, which is very important in reduction of these pollutants in our environment Blending of biodiesel with diesel could be a healthier option for PAHs reduction in diesel driven automobiles. Biodiesel was blended with Diesel, the concentration of almost all carcinogenic PAHs reduces in comparison to pure Diesel automobile. This shows that blending of Diesel with different Biodiesel reduces the concentration of almost PAHs emission and it could be a better fuel as compared to diesel in terms of carcinogenicity.

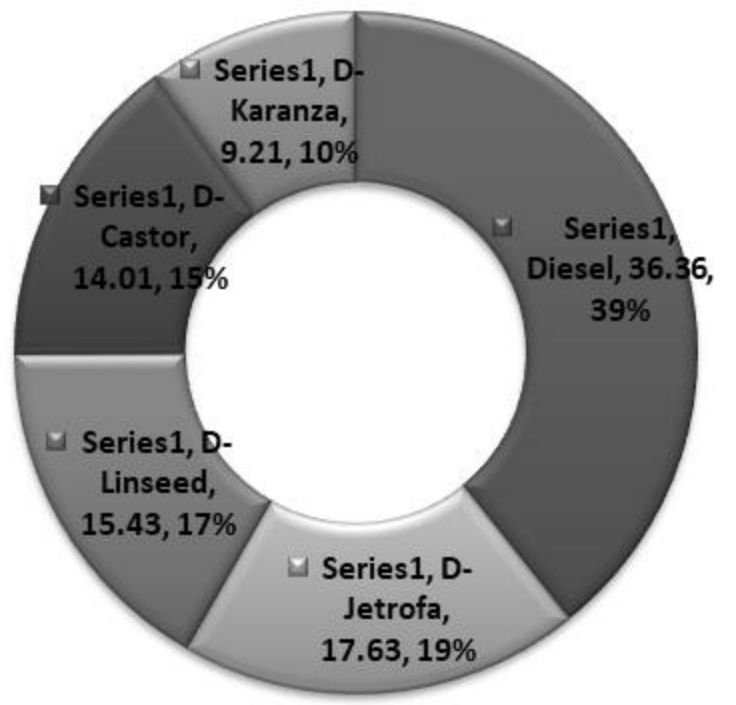

Figure 6. Emission (\%) of AHCs from different blending ratios of diesel and biodiesel

Table 3. AHCs levels produced by diesel and different biodiesel ratios (20:80, 30:70, 40:60)

\begin{tabular}{|c|c|c|c|c|c|c|c|c|c|c|c|c|c|}
\hline \multirow[b]{2}{*}{ AHCs } & \multirow[b]{2}{*}{$\begin{array}{l}\bar{\Phi} \\
\stackrel{\bar{\Delta}}{\Delta}\end{array}$} & \multicolumn{4}{|c|}{$\mathrm{D}: \mathrm{BD}=\mathbf{2 0 : 8 0}$} & \multicolumn{4}{|c|}{$\mathrm{D}: \mathrm{BD}=\mathbf{3 0 : 7 0}$} & \multicolumn{4}{|c|}{$\mathrm{D}: \mathrm{BD}=40: 60$} \\
\hline & & $\begin{array}{l}\frac{\pi}{2} \\
\frac{0}{0} \\
0 \\
\frac{\pi}{2} \\
\frac{\pi}{2}\end{array}$ & 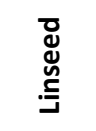 & 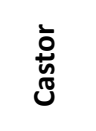 & $\begin{array}{l}\mathbb{N} \\
\stackrel{N}{0} \\
\frac{\pi}{\pi} \\
\stackrel{\pi}{\pi}\end{array}$ & $\begin{array}{l}\frac{\pi}{2} \\
\frac{0}{0} \\
\frac{0}{2} \\
\frac{\pi}{2}\end{array}$ & 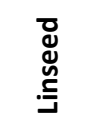 & 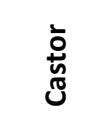 & $\begin{array}{l}\mathbb{N} \\
\stackrel{N}{N} \\
\frac{\pi}{\pi} \\
\stackrel{\pi}{\pi}\end{array}$ & 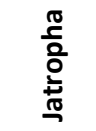 & 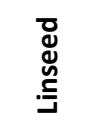 & 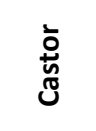 & 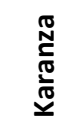 \\
\hline BEN & 4.57 & 2.45 & 2.08 & 2.00 & 0.73 & 1.72 & 1.52 & 1.51 & 0.38 & 1.45 & 1.07 & 1.16 & 0.05 \\
\hline TOL & 5.41 & 3.29 & 2.92 & 2.38 & 1.31 & 2.56 & 2.36 & 1.89 & 0.95 & 2.29 & 1.91 & 1.54 & 0.62 \\
\hline $\mathrm{XYL}$ & 3.47 & 1.35 & 1.01 & 0.84 & 0.68 & 0.62 & 0.45 & 0.35 & 0.33 & 0.35 & $\mathrm{BDL}$ & $\mathrm{BDL}$ & $\mathrm{BDL}$ \\
\hline CHR & 7.21 & 5.09 & 4.72 & 4.18 & 3.10 & 4.36 & 4.16 & 3.69 & 2.75 & 4.09 & 3.71 & 3.34 & 2.42 \\
\hline BAP & 7.84 & 5.71 & 5.35 & 4.81 & 3.71 & 4.98 & 4.79 & 4.32 & 3.38 & 4.71 & 4.34 & 3.97 & 3.05 \\
\hline BAA & 7.86 & 5.75 & 5.41 & 4.84 & 3.75 & 5.02 & 4.85 & 4.35 & 3.42 & 4.74 & 4.40 & 4.00 & 3.07 \\
\hline $\begin{array}{c}\text { Average } \\
\text { Total }\end{array}$ & 36.36 & 23.64 & 21.49 & 19.05 & 13.28 & 19.26 & 18.13 & 16.11 & 11.21 & 17.63 & 15.43 & 14.01 & 9.21 \\
\hline
\end{tabular}

AHCs- Aromatic Hydrocarbons, D:BD- Diesel:Biodiesel Ratio, BEN- Benzene, TOL- Toluene, XYL- Xylene, CHR- Chrysene, BAP-Benzo(a)pyrene, BAABenzo(a)anthracene

\subsection{Mutagenicity test}

We examined the human cell mutagenicity of diesel engine exhaust fine particulate matter and found subfractions containing unsubstituted polycyclic aromatic compounds
(PACs) responsible for a considerable portion of the mutage nic potency of the whole atmospheric sample. In this test, several strains of the bacterium Salmonella typhimurium were used that carry mutations in genes involving inhistidine synthesis. These strains are 
auxotrophic mutants, i.e. they require histidine for growth, but cannot produce it. This method examines the capability of a substance in creating mutations which in turn results to a "prototrophic" state, so that the cells can grow on a histidine-free medium (Mauderly, 1987; Shankar, 1990; Morris et al., 1995; Petry et al., 1996). Figure 7 depicts that the percentage contribution of $\mathrm{B}(\mathrm{a}) \mathrm{P}$ and $\mathrm{B}(\mathrm{a}) \mathrm{A}$ was $26 \%$ each, followed by chrysene (22\%), toluene (12\%), benzene (9\%) and xylene (5\%) whereas chrysene accounted for most of the mutagenic potencies that could be assigned to specific compounds within the atmospheric samples.

Table 4 indicated the individual AHCs contributions to human mutagenicity of diesel engine exhaust airborne fine particle. High mutagenicity concentration of AHCs especially Chrysene (15.02 IMF) is a matter of concern in diesel engine exhaust.

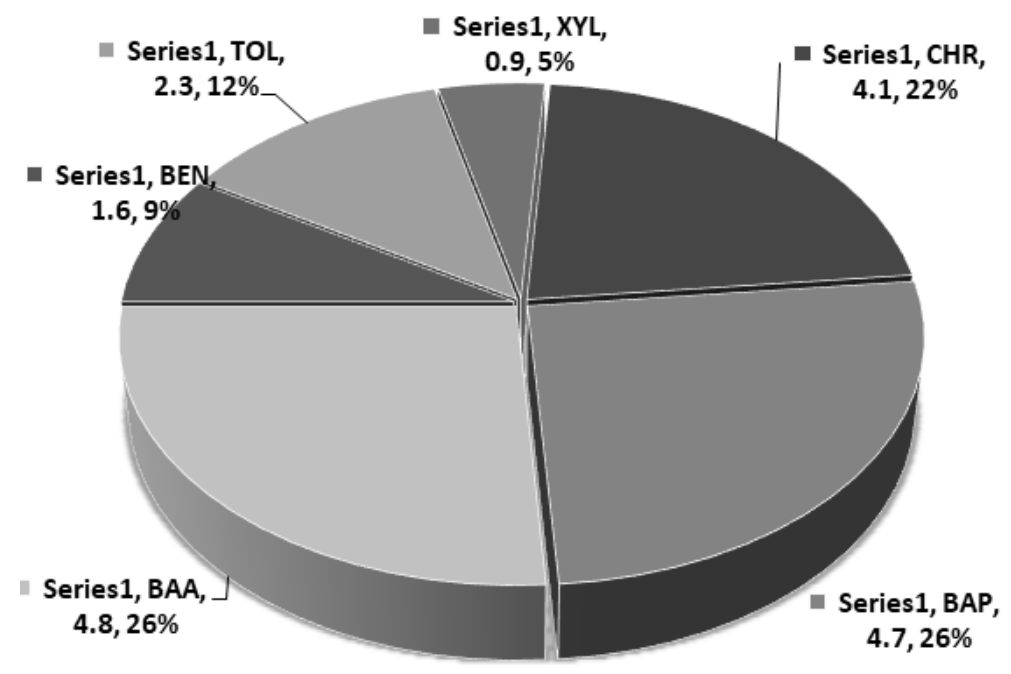

Figure 7. Percentage contribution of AHCs from exhaust of engine

Table 4. Individual AHCs contributions to human mutagenicity of diesel engine exhaust airborne fine particle

\begin{tabular}{cccc}
\hline Sr. No. & AHCs & IMF $\left(\mathbf{X ~ 1 0 ^ { 6 }}\right) / \mathbf{~} \mathbf{~ o f ~ E O C ~}$ & Sources \\
\hline 1 & Chrysene & $15.02-5.31$ & Diesel engine exhaust \\
\hline 2 & $\mathrm{~B}(\mathrm{a}) \mathrm{P}$ & $5.02-0.85$ & Diesel engine exhaust \\
\hline 3 & $\mathrm{~B}(\mathrm{a}) \mathrm{A}$ & $4.02-0.51$ & Diesel engine exhaust \\
\hline 4 & Benzene & $3.55-1.02$ & Diesel engine exhaust \\
\hline 5 & Toluene & $3.12-2.01$ & Diesel engine exhaust \\
\hline 6 & Xylene & $3.02-0.55$ & Diesel engine exhaust
\end{tabular}

\subsection{Toxic equivalency factors and lifetime lung cancer risk}

Several AHCs species including benzo(a)pyrene (as most carcinogenic compound) have been classified into probable (2A) or possible (2B) human carcinogens by the International Agency for Research on Cancer (IARC, 1987). $\mathrm{BaP}$ is a five ring $\left(\mathrm{C}_{20} \mathrm{H}_{12}\right)$ compound, which is mutagenic for human cells in culture (Osborne and Crosby, 1987) and carcinogenic in whole animal assays (Cerna et al., 2000). According to the literature (Kumar et al., 2015), the toxic equivalent factor for $\mathrm{BaP}$ is one (1), which is highest among all the AHCs. In order to calculate the carcinogenic potencies associated with the total $A H C$ exposures from D/BD exhaust; we pragmatically used the sum of each individual BaPeq (i.e., total-BaPeq) as a surrogate indicator. Therefore, in the present study toxic equivalent factor (TEF) of the given species relative to BaP carcinogenic potency have been used. Toxicity equivalency concentrations (TEQs) were calculated as the product of summing up the values obtained by TEF values and concentrations of AHCs, as follows (Kumar et al., 2015):

$\mathrm{TEQ}=\Sigma(\mathrm{Ci} \times \mathrm{TEFi})(2)$

where, TEQ: toxic equivalent concentration, Ci: concentration of $\mathrm{AHCi}$.

The above method has the main advantage of being relatively easy to apply in the environments affected by human sources, however, may underestimate risk due to not all AHC, but only limited compounds, are considered (WHO/IPCS, 1998). For pragmatic purpose, the list of TEFs compiled by Bieniek \& Łusiak (2012) and Masih et al. (2009) was adopted in this study.

Table 5 depicts the AHCs exposure levels from diesel exhaust is 8.7 , whereas it is reduced almost to half by using BD/D blends in the ratios of 20:80,30:70 and 40:60 having $5.4,4.8$ and 4.4 respectively. Moreover, according to WHO, the risk of developing lung cancer is calculated as follows, 
Lifetime lung cancer risk $=\mathrm{B}(\mathrm{a}) \mathrm{P}$-eq $\left(\mathrm{ng} / \mathrm{m}^{3}\right) \times$ UR $/ 70$ (years) (3)

(where UR $=$ unit risk of $12.7 \times 10^{-5}$ for chronic inhalational exposure to $1 \mathrm{ng} / \mathrm{m}^{3} \mathrm{~B}(\mathrm{a}) \mathrm{P}$ over a lifetime of 70 years).

In the present study, diesel engine exhaust showed the highest estimated risk with values of $1.6 \mathrm{E}-05$ whereas, blending of diesel with bio diesel in different ratios of $20: 80,30: 70$ and 40:60 shows the estimated risks of 9.7E-06, 8.7E-06 and 7.9E-06 respectively which were found to be much lower than diesel engine exhaust emission. It is evident from the results that blending of diesel with biodiesel reduces lifetime lung cancer risk up to an extent.

Table 5. Toxic Equivalence Factor (TEF) of AHCS

\begin{tabular}{cccccccccc}
\hline AHCs & TEF & $\begin{array}{c}\text { Diesel } \\
\text { (only) }\end{array}$ & Exposure & $\begin{array}{c}\text { BD+D } \\
(\mathbf{2 0 : 8 0 )}\end{array}$ & Exposure & $\begin{array}{c}\text { BD+D } \\
(\mathbf{3 0 : 7 0 )}\end{array}$ & Exposure & $\begin{array}{c}\text { BD+D } \\
(\mathbf{4 0 : 6 0 )}\end{array}$ & Exposure \\
\hline BEN & 0.001 & 4.57 & 0.00457 & 1.815 & 0.001815 & 1.2825 & 0.001283 & 0.9325 & 0.000933 \\
\hline TOL & 0.001 & 5.41 & 0.00541 & 2.475 & 0.002475 & 1.94 & 0.00194 & 1.59 & 0.00159 \\
\hline XYL & 0.001 & 3.47 & 0.00347 & 0.97 & 0.00097 & 0.4375 & 0.000438 & 0.35 & 0.00035 \\
\hline CHR & 0.01 & 7.21 & 0.0721 & 4.2725 & 0.042725 & 3.74 & 0.0374 & 3.39 & 0.0339 \\
\hline BAA & 0.1 & 7.86 & 0.786 & 4.9375 & 0.49375 & 4.41 & 0.441 & 4.0525 & 0.40525 \\
\hline BAP & 1 & 7.84 & 7.84 & 4.895 & 4.895 & 4.3675 & 4.3675 & 4.0175 & 4.0175 \\
\hline & & & $\mathbf{8 . 7 1 1 5 5}$ & $\mathbf{5 . 4 3 6 7 3 5}$ & & $\mathbf{4 . 8 4 9 5 6}$ & & $\mathbf{4 . 4 5 9 5 2 3}$ \\
\hline
\end{tabular}

AHCS: aromatic hydrocarbons, TEF: toxic equivalent factors, BD: biodiesel, $D$ : diesel

\section{Conclusion}

This study provides first comprehensive information on AHCs reduction of carcinogenic pollutants from the diesel exhaust in India. Results indicated that order of emission of AHCs from the exhaust of engine was as follow: Diesel>Jatropha-diesel>Linseed-diesel>Castor-

diesel>Karamza-diesel. B(a)P was the individual AHC found in higher concentration. Chrysene was found with high mutagencity. Six AHCs of this study were found to indicate positive test of mutagencity is a matter of concern in urban environment. Blending of biodiesel with diesel could be a better option for AHCs reduction in diesel driven vehicles, which is a serious problem in the developing cities of India like Jalandhar. When biodiesel was added to diesel then concentration of almost all AHCs reduces in comparison to pure Diesel exhaust. The best obtained ratio was (40:60), which could be used for reduction of toxic pollutants from environment. Therefore, chemically processed biodiesel and its blends with diesel fuel can give a slightly improved performance. The AHCs emission levels with biodiesels/diesel blend with mode of operation were lower than diesel mode of operation. Operation of engine with biodiesel blends and with optimum parameters gives better performance and lower emissions. This type of work seems to reduce the hydrocarbon opacity with better performance.

\section{References}

Abebe K., Endalew, Yohannes K., and Rolando Zanzi (2011), Heterogeneous catalysis for biodiesel production from Jatropha curcas oil (JCO), Energy, 36, 2693-2700.

Baek S.O., Field R.A., Goldstone M.E., Kirk P.W., Lester J.N. and Perry R. (1991), A review of atmospheric Polycyclic Aromatic Hydrocarbons: sources, fate and behavior, Water, Air and Soil Pol., 60, 279-300.

Benner B.A., Gordon G.E. and Wise S.A. (1989), Mobile sources of atmospheric Polycyclic Aromatic Hydrocarbons: A roadway tunnel study, Environ. Sci. Technol., 23, 1269-1278.

Bieniek G. and Łusiak A. (2012), Occupational Exposure to Aromatic Hydrocarbons and Polycyclic Aromatic
Hydrocarbons at a Coke Plant, Annals of Occupational Hygiene, 56(7), 796-807, DOI: 10.1093/annhyg/mes016

Bond J.A. (1990), Concentration- and time-dependent formation of DNA adducts in lungs of rats exposed to diesel exhaust, Toxicology, 60, 127-135.

Caricchia A.M., Chiavarini S and Pezza M. (1999), Polycyclic aromatic hydrocarbons in the urban atmospheric particulate matter in the city of Naples (Italy), Atmospheric Environ., 33, 3731-3738.

Cerna M., Pochmanova D., Pastorkova A., Bene I., Lenicek J., Topinka J., and Binkova B. (2000), Genotoxicity of urban air pollutants in the Czech Republic Part I. Bacterial mutagenic potencies of organic compounds adsorbed on PM10 particulates, Mutat. Res.-Gen. Toxicol., 469, 71-82.

Demirbas A. (2009), Production of biodiesel fuels from linseed oil using methanol and ethanol in non-catalytic SCF conditions, Biomass and Bioenergy, 33, 113-118.

International Agency for Research on Cancer (IARC), 1987. IARC Monographs on the evaluation of the carcinogenic risk of chemicals to humans, Suppl. 7. IARC, Lyons.

Kauppinen T. (2001), Finnish occupational exposure databases, J Occup Environ Hyg., 16, 154-158.

Kumar V. and Kothiyal N.C. (2011b), Estimation of Polycyclic Aromatic Hydrocarbons (PAHs) in diesel-biodiesel blends by GC Technique, Journal of Environmental Research and Development, 5(3), 584-590.

Kumar V. and Kothiyal N.C. (2012), Distribution behavior and carcinogenic level of some polycyclic aromatic hydrocarbons in roadside soil at major traffic intercepts within a developing city of India, Environ Monit Assess., 184(10), 6239-6252.

Kumar V., Kothiyal N.C. and Saruchi (2014), Studies on carcinogenic PAHs emission generated by vehicles and its correlation to fuel and engine types, Polish Journal of Chemical Tech., 16(1), 48-58.

Kumar V., Kothiyal N.C. and Saruchi (2015), Analysis of Polycyclic Aromatic Hydrocarbon, Toxic Equivalency Factor and Related Carcinogenic Potencies in Roadside Soil within a Developing City of Northern India, Polycyclic Aromatic Compounds, 36(4), 506-526. 
Kumar V., Kothiyal N.C., Saruchi and Masih A. (2014a), Environmental fate and behavior of some PAHs at roadside ambient air in a fast-developing city environment of Northern India, Journal of Chinese Advanced Materials Society, 2(2), 8298.

Masih A. and Taneja A. (2006), Polycyclic Aromatic Hydrocarbons (PAHs) concentrations and related carcinogenic potencies in soil at a semi-arid region of India, Chemosphere, 65(3), 449-456.

Masih A., Saini R., Singhvi R. and Taneja A. (2009), Concentration, sources and exposure profiles of PAHs in particulate matter (PM10) in the north central part of India, Environ Monit Assess, 163, 421-431.

Mauderly J.L. (1987), Diesel exhaust is a pulmonary carcinogen in rats exposed chronically by inhalation, Fundamental and Applied Toxicology, 9, 208-221.

MCClellan R.O. (1987), Health effects of exposure to diesel exhaust particles, Annual Review of Pharmacology and Toxicology, 27, 279-300.

Morris W.A., Versteeg J.K., Bryant D.W., Legzdins A.E., McCarry B.E. and Marvin C.H. (1995), Preliminary comparisons between mutagenecity and magnetic susceptibility of respirable airborne particle, Atmos. Environ., 29(23), 3441-3450.

Osborne M.R. and Crosby N.T., 1987. Benzopyrenes. Cambridge University Press, Cambridge, UK

Petry T., Schmid P and Schlater C (1996), The use of toxic equivalency factors in assessing occupational and environmental health risk associated with exposure to airborne mixtures of polycyclic aromatic hydrocarbons (PAHs), Chemosphere, 32, 639-648.

Salmeen I.T., Pero A.M., Zator R., Schuetzle D. and Riley T.L. (1984), Environ. Sci.Technol., 18, 375-382.

Satyarthi J.K., Srinivas D. and Ratnasamy P. (2009), Estimation of free fatty acid content in oils, fats, and biodiesel by ${ }^{1} \mathrm{H}$ NMR Spectroscopy, Energy and Fuel, 23, 2273-2277.

Shankar RV. Characterization of atmospheric polynuclear aromatic hydrocarbons with special reference to automobile exhaust. 1990: Ph.D. Thesis. Jawaharlal Nehru University, New Delhi, India.

USEPA, (2009). Technical Assistance document for the National Air Toxics trends stations program for Office of Air Quality Planning and Standards (C304-06), Research Triangle Park, NC 27711. Eastern Research Group, Inc. 601 Keystone Park Drive, Suite 700 Morrisville, NC 27560.

WHO/IPCS, 1998. Environmental Health Criteria 202 Selected non-Heterocyclic PAHs. WHO, Geneva. 